\title{
OPTIMALISASI CLOUD STORAGE UNTUK AKSESBILITAS DATA IMAGE PADA MOBILE APPS DI STMIK AMIK RIAU
}

\author{
Torkis Nasution \\ Program Studi Teknik Informatika, STMIK Amik Riau, Jl. Purwodadi Indah Km. 10 Panam \\ email: torkisnasution@stmik-amik-riau.ac.id
}

\begin{abstract}
In increasing accessibility to data, it is necessary to consider cloud storage media. The application that is built makes it possible to access data into information so that users can use it optimally. The impact of using a smartphone, one of which is to take photo documentation for a variety of purposes including the use for documentary proof of activity. At this time there is no official data storage media available yet. Difficult to identify the historical of a digital image photo in detail. Activation photos are available in every activity, but when needed they are not available and there is no photo capture application integrated with the agenda. Although every activity is available documentation, but not managed based on technology. Cloud technology has become a trend in data management, but can not be utilized optimally. This research will provide an application that can be used to capture photos automatically uploaded to cloud storage. Android-based smartphone devices are chosen because they are generally affordable and commonly used. Each uploaded photo is equipped with time, coordinates, momentum, and location information. The application has been tested black box with $76.5 \%$ reliability accuracy.
\end{abstract}

Keywords: android, attribute foto, cloud storage, database foto, foto capture

\begin{abstract}
Abstrak
Dalam meningkatkan aksesibilitas terhadap data, perlu mempertimbangkan media penyimpanan cloud storage. Aplikasi dapat mengakses data menjadi informasi sehingga user dapat menggunakan secara optimal. Pada saat ini belum tersedia media penyimpanan data resmi. Sulit mengidentifikasi historis sebuah foto secara detail. Foto aktivitasi telah ada di setiap kegiatan, namun pada saat dibutuhkan tidak tersedia dan belum ada aplikasi foto capture yang terintegrasi dengan agenda. Walaupun setiap kegiatan tersedia dokumentasi, namun tidak dikelola berbasis teknologi. Cloud storage sudah menjadi trend dalam pengelolaan data, namun belum dimanfaatkan secara optimal. Penelitian ini menyediakan aplikasi yang dapat digunakan untuk meng-capture foto secara otomatis upload ke cloud storage. Perangkat smartphone berbasis Android, secara umum terjangkau dan umum digunakan. Setiap foto yang di upload dilengkapi dengan informasi waktu, koordinat, momentum, dan lokasi. Aplikasi telah dilakukan uji black box dengan akurasi kehandalan $76.5 \%$.
\end{abstract}

Keywords: android, attribut foto, cloud storage, database foto, foto capture

\section{PENDAHULUAN}

Cloud Storage adalah sebuah teknologi penyimpanan data digital yang memanfaatkan ketersediaan server virtual (Mahedy, 2017). Tidak seperti media penyimpanan umumnya seperti Compact Disk hard disk atau flash disk, teknologi cloud storage tidak membutuhkan perangkat tambahan apapun. Ketersediaan Internet sudah cukup untuk mengakses file digital pada cloude storage. Pemanfaatan cloud storage untuk media penyimpanan online, dapat diartikan dari dua kata penyusunnya (Oktafeearto et al., 2019), cloud dan storage. Cloud yang dalam bahasa Indonesia berarti awan merupakan sebuah ibarat kata dari Internet. Internet diibaratkan layaknya sebuah awan yang luas yang mampu menampung banyak hal mulai dari informasi, hingga $p$ rogram-program dalam satu tempat dan dapat dimanfaatkan dengan mudah oleh banyak orang. Sedangkan kata storage memiliki arti penyimpanan atau media penyimpanan, dalam hal ini yang dapat disimpan adalah data-data digital mulai dari data tertulis, audio, visual hingga program atau pun aplikasi digital. Jadi secara umum cloud storage dapat diartikan (Santiko \& Rosidi, 2018) sebagai teknologi yang menggunakan internet sebagai media penyimpanan data-data digital.

Pada dasarnya teknologi cloud storage merupakan pengembangan dari sistem 
komputasi awan atau yang disebut juga dengan istilah cloud computing (Mahedy, 2017). Komputasi awan merupakan konsep dasar dari adanya layanan cloud storage. Dengan penerapan teknologi komputasi awan, penyedia layanan cloud storage bisa membangun media penyimpanan secara online tersebut. Sistem operasi Android telah mendominasi pada perangkat smartphone dalam pasar global. Pada kurun waktu April 2018 sampai April 2019 Sistem operasi android menempati posisi pertama dengan market share 78\% (GlobalStats, 2019).

Setiap kegiatan selalu membuat dokumentasi dalam bentuk foto. Pemaknaan dokumentasi kegiatan, adalah segala sesuatu yang berhubungan dengan foto dan video. Awalnya media yang digunakan untuk mengambil gambar adalah kamera Single Lens Reflect (SLR), namun seiring dengan meningkatnya kualitas kamera Digital Single Lens Reflect (DSLR) (ID, 2019) penggunaan kamera yang sudah tersedia smartphone semakin umum. Permasalahan adalah belum ada aplikasi foto capture beserta atribut yang diperlukan dan terintegrasi dengan agenda milik kampus, serta belum tersedia media penyimpanan foto milik kampus yang dapat dilihat secara realtime, umumnya disimpan dalam harddisk, atau tersebar pada komputer masing-masing pegawai

Idealnya, gambar digital yang tersedia dapat di eksplorasi dengan melakukan penambahan informasi (Croci et al., 2020) kemudian menyajikan pada moment yang tepat dapat meningkatkan citra kampus dimata stakeholder. Begitu juga, pada kesempatan tertentu misalnya dalam Dies Natalis, family ghatering, dan kegiatan lain. Pemecahan masalah adalah membangun aplikasi berbasis smartphone, memiliki kemampuan menangkap gambar. Aplikasi memperbaharui dengan menambah informasi yang dibutuhkan pada gambar atau terpisah secara otomatis meng-upload ke cloud storage. Pada sistem cloud storage (Kurniawan et al., 2016) sudah tersedia database yang telah di rancang untuk menyimpan informasi yang dikirim dari perangkat smartphone. Begitu juga pada saat mengambil gambar, seseorang yang memiliki otorisasi dapat langsung membuka portal website yang telah disediakan untuk memilah gambar yang diperlukan. Bentuk blok diagram ditunjukkan pada gambar 1.

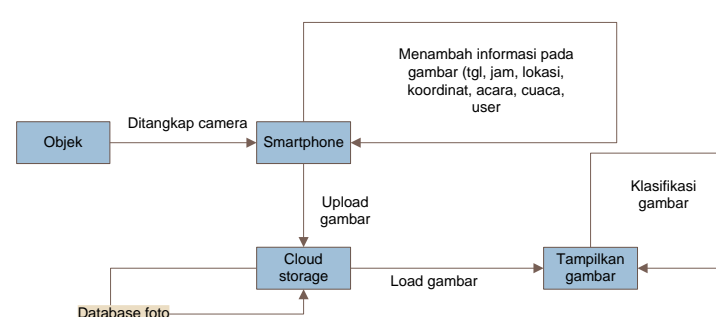

Gambar 1. Aplikasi database foto berbasis cloud storage

Penelitian ini mendukung sepenuhnya visi dan misi STMIK Amik Riau yaitu menjadi Perguruan Tinggi Unggul di Sumatera 2030. Fokus unggul yang dimaksud dalam visi dan misi tersebu adalah dalam bidang mobile. Dalam pemanfaatan teknologi, penelitian ini penting untuk menata kebiasaan mengambil gambar untuk dokumentasi. Begitu juga dengan penetrasi teknologi di lingkungan kampus akan lebih nyata, karena pegawai langsung berintegrasi ke dalam teknologi terkini, yaitu bagian dari cloud computing.

\section{METODE PENELITIAN}

Penelitian diawali penetapan topik penelitian, yaitu upload foto dari device mobile secara otomatis ke cloud storage. Selanjutnya, menetapkan masalah yang akan diangkat, tidak tersedia dokumentasi foto, Tujuan penelitian ini adalah membuat aplikasi yang mampu menangkap objek menjadi citra digital, membubuhi informasi, dan mengupload ke eksternal storage secara otomatis, serta menyediakan aplikasi untuk menampilkan foto. Teknik pengumpulan data (Sudaryono, 2019) yang digunakan adalah skala atau kuisioner, wawancara, observasi, dan dokumentasi, serta literatur. Pengumpulan data menggunakan teknik observasi, wawancara, studi pustaka.

Dalam penelitian kualitatif (Herdiansyah, 2019), data berbentuk hasil analisis mengunakan kata-kata bukan berupa angka tetapi hasil diperoleh dari pengamatan dilapangan. Analisis kualitatif digunakan pada data yang diperoleh dari hasil observasi tentang kebiasaan karyawan dalam mengambil foto serta mendokumentasikan. Dalam pengumpulan data dari dua sudut yaitu dari tenaga pendidik dan tenaga kependidikan. Data tersebut diolah dan dianalisis untuk perencanaan pembelajaran berikutnya. Dalam melakukan analisis data harus berdasarkan tahapan, yaitu: langkah-langkah dalam adalah tahap analisis data pengumpulan data, tahap 
editing, tahap coding, tahap pengujian, tahap mendeskripsikan data. dan tahap pengujian hipotesis.

\section{HASIL DAN PEMBAHASAN}

\subsection{Analisa Kebutuhan}

Kebutuhan perangkat lunak adalah kondisi, kriteria, syarat atau kemampuan yang harus dimiliki oleh perangkat lunak untuk memenuhi apa yang disyaratkan atau diinginkan pemakai. Adapun analisa kebutuhan adalah:

1. Kebutuhan fungsional, berkaitan dengan fungsi atau proses transformasi yang harus mampu di kerjakan oleh system.

2. Kebutuhan antarmuka, menghubungkan perangkat lunak dengan elemen perangkat keras, perangkat lunak.

3. Kebutuhan unjuk kerja, menetapkan karakteristik unjuk kerja yang harus dimiliki oleh perangkat lunak berupa perangkat lunak harus bisa menangani multi upload data, penggunaan multiuser sesuai dengan otoritas yang diberikan pada user, dan waktu tanggap penyajian informasi secara optimal.

4. Kebutuhan Teknologi: smartphone, server, dan akses data.

\subsection{Hasil Perancangan Perangkat Lunak}

Perancangan perangkat lunak terdiri dari use case, dan class diagram.

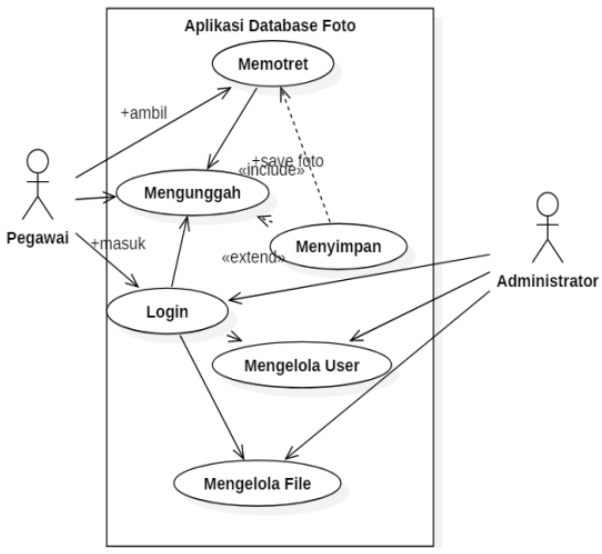

Gambar 2. Uses Case Aplikasi Foto

Tabel 1. Penjelasan Use Case Aplikasi Foto

\begin{tabular}{ll}
\hline Use Case & Deskripsi \\
\hline Memotret & Merupakan proses pengambilan gambar, \\
& melalui perangkat smartphone, foto yang \\
& telah di ambil dapat langsung di simpan \\
& di server atau di unggah sendiri oleh user \\
\hline
\end{tabular}

\begin{tabular}{|c|c|}
\hline $\begin{array}{l}\text { Meng- } \\
\text { unggah }\end{array}$ & $\begin{array}{l}\text { Merupakan proses mengunggah file yang } \\
\text { telah di ambil sebelumnya, tidak } \\
\text { langsung di simpan karena alasan tertentu }\end{array}$ \\
\hline $\begin{array}{l}\text { Menyim- } \\
\text { pan }\end{array}$ & $\begin{array}{l}\text { Merupakan proses menyimpan file } \\
\text { gambar beserta informasi pada cloud } \\
\text { storage }\end{array}$ \\
\hline Login & $\begin{array}{l}\text { Merupakan proses masuk ke dalam } \\
\text { sistem untuk mengakses gambar yang } \\
\text { telah disimpan pada cloud storage yang } \\
\text { dilakukan oleh pegawan dan } \\
\text { administrator }\end{array}$ \\
\hline $\begin{array}{l}\text { Mengelola } \\
\text { User }\end{array}$ & $\begin{array}{l}\text { Proses mengelola user menambah user, } \\
\text { menghapus user, menampilkan user }\end{array}$ \\
\hline $\begin{array}{l}\text { Mengelola } \\
\text { File }\end{array}$ & $\begin{array}{l}\text { Merupakan proses menampilkan, } \\
\text { memperbaharusi informasi, menghapus, } \\
\text { maupun mengubah status file. }\end{array}$ \\
\hline
\end{tabular}

Perancangan class diagram, terdiri dari 13 class, yang berjalan di sisi server dan client.

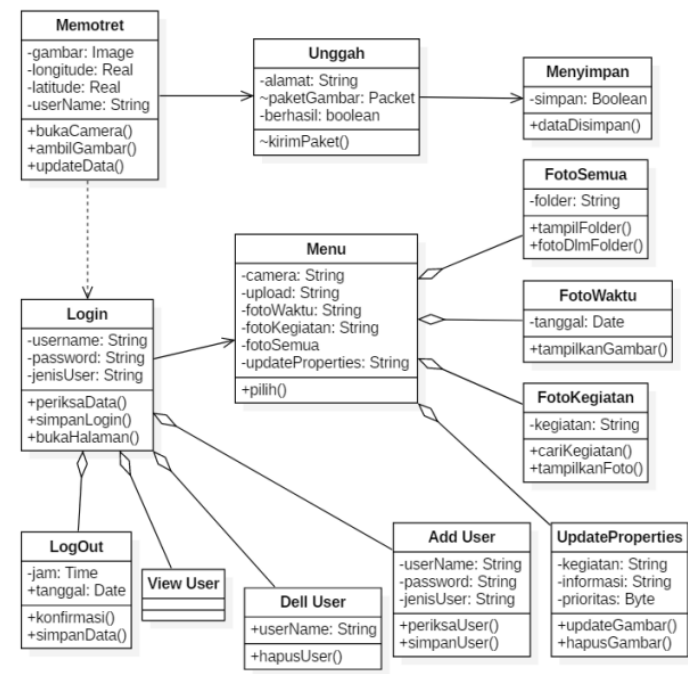

Gambar 3. Class Diagram Aplikasi Foto

\subsection{Arsitektur Jaringan}

Perancangan arsitektur jaringan yang dibangun menggunakan (Hidayat et al., 2017) konsep jaringan client-server, server menggunakan web apache dan client menggunakan mobile smartphone menggunakan sistem operasi android. Web Server merupakan web yang bertujuan menghubungkan suatu platform aplikasi dengan platform lainnya sehingga seluruh aplikasi tersebut dapat saling berkomunikasi. Web Server pada penelitian ini dibangun menggunakan bahasa pemograman PHP yang dikombinasikan dengan JSON. JSON atau JavaScript Object Notation merupakan suatu format pertukaran data antara komputer dengan komputer ataupun perangkat mobile dengan komputer. Database digunakan untuk menyimpan data-data yang dibutuhkan oleh aplikasi pada bagian ini di implementasikan 
menggunakan MySQL. Akses koneksi jaringan yang digunakan dari aplikasi mobile ke jaringan lokal dapat juga dilakukan dengan sambungan BTS (Base Transceiver Station) melalui perangkat mobile menggunakan jaringan GPRS, EDGE, $3 G$ ataupun HSDPA. Pada jaringan lokal STMIK Amik Riau, dapat menggunakan jaringan internal yang tersedia.

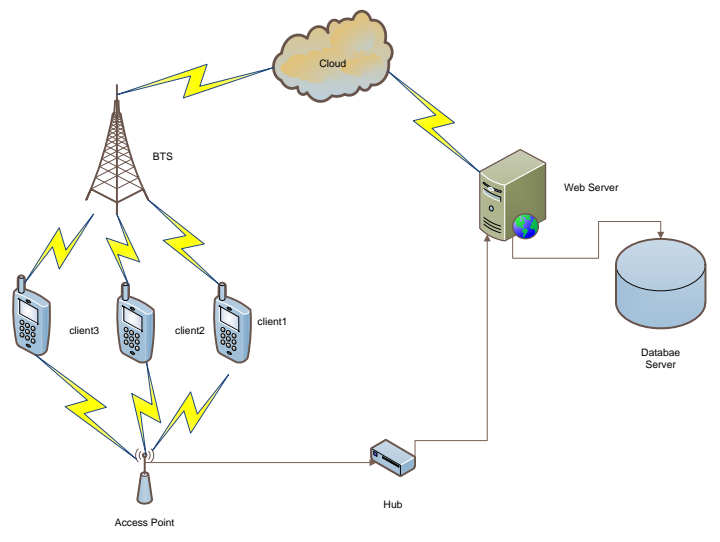

Gambar 4. Arsitektur Jaringan

\subsection{Desain Tampilan}

Desain tampilan yang di buat dalam penelitian ini mencakup dari sisi perangkat bergerak untuk mengambil foto.

1. Desain pengambil gambar, meng-upload ke server melalui jaringan internet.

2. Desain menu utama, untuk mengakses gambar pada server juga digunakan untuk melakukan upload gambar ke server. Bentuk tampilan sederhana namun memenuhi fungsi yang dibutuhkan.

3. Desain tampilan foto semua, menampilkan semua foto pada sisi server, namun di sajikan untuk setiap folder.

4. Desain tampilan foto kegiatan, tampilan foto berdasarkan kegiatan.

5. Desain tampilan foto waktu, menampilkan foto pada server berdasarkan pada waktu pengambilan.

\subsection{Konseptual Database}

Database yang digunakan dalam Aplikasi database foto berbasis cloud storage menggunakan MySQL. Table yang digunakan berjumlah 5, dua table berfungsi untuk managemen user, dan 3 table yang lain berfungsi untuk penyimpanan foto.

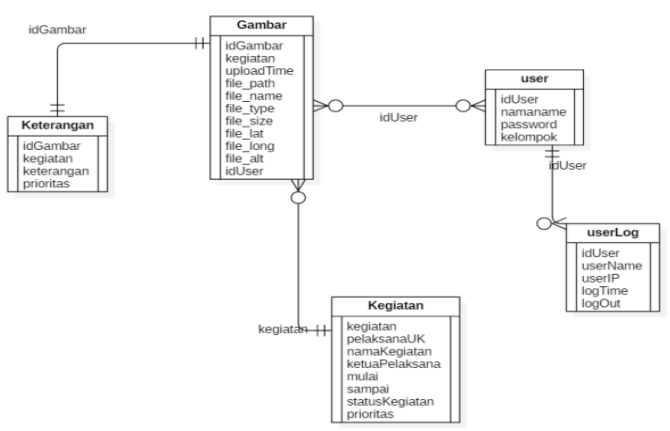

Gambar 5. Kosenp Database

\subsection{Pembahasan}

Implementasi antar muka menampilkan layar dialog interaksi antara user dengan aplikasi Optimasi Penyusunan Jadwal Matakuliah dan Manajemen Pengendalian Perkuliahan. Layar dialog dirancang secara optimal dan user frendly, sehingga user betah dan tidak bosan selama menggunakan aplikasi. Implementasi antarmuka adalah:

1. Layar dialog administrator, akses aplikasi diawali dengan membuka domain di http://localhost/fotostoragel/index.php, selanjutnya akan tampil layar dialog login. Halaman ini berfungsi melakukan otorisasi terhadap user yang akan masuk ke dalam sistem. User dibedakan terhadap kelompok Kependidikan, Pendidik, dan Administrator.

2. Halaman Administrator

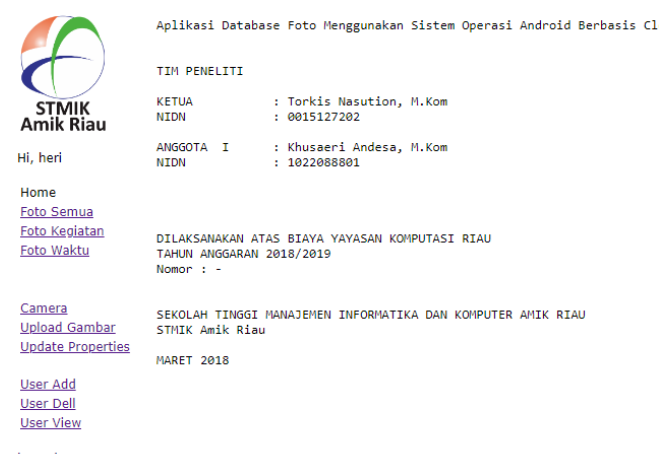

Gambar 6. Halaman Administrator

3. Halaman Pengguna

Halaman pengguna dibuat terpisah dengan halaman administrator, dengan perbedaan pada halaman pengguna tidak tersedia menu Update Propertis, User Add, User Dell, dan User View. 


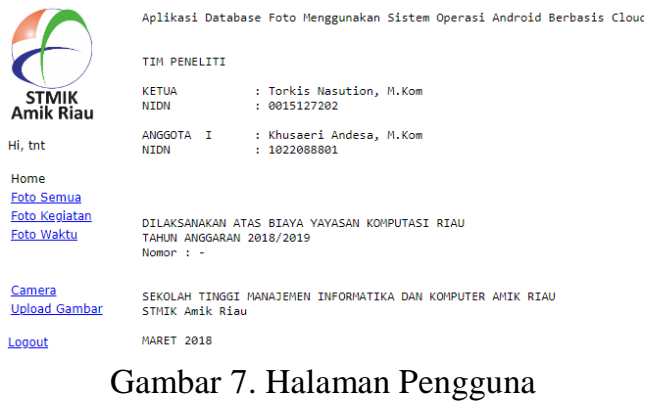

4. Halaman Kegiatan

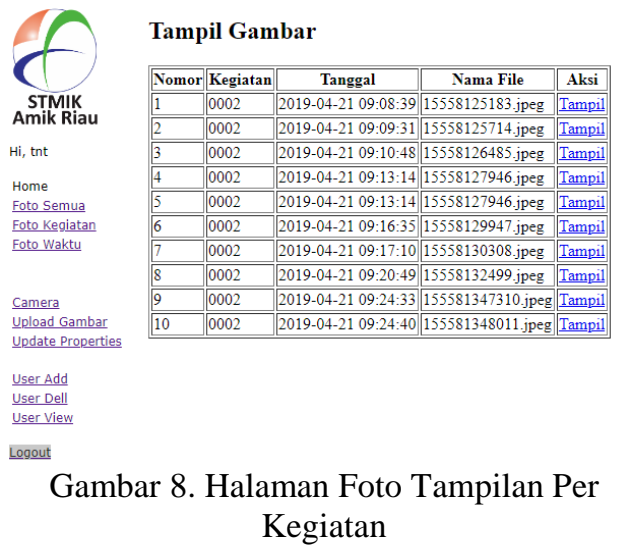

5. Halaman Tampilan Foto Berdasarkan Waktu

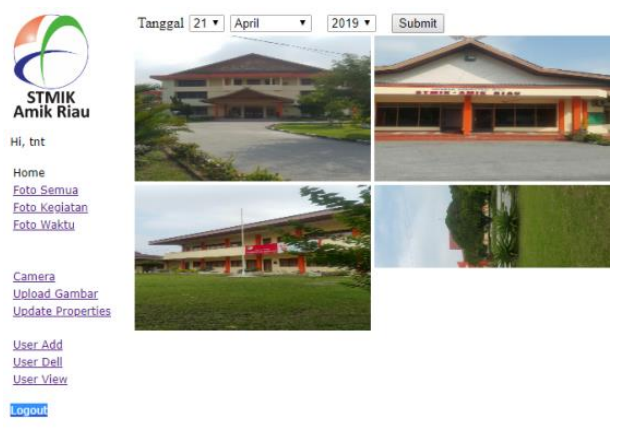

Gambar 9. Tampilan Foto berdasarkan waktu

6. Halaman Upload Gambar

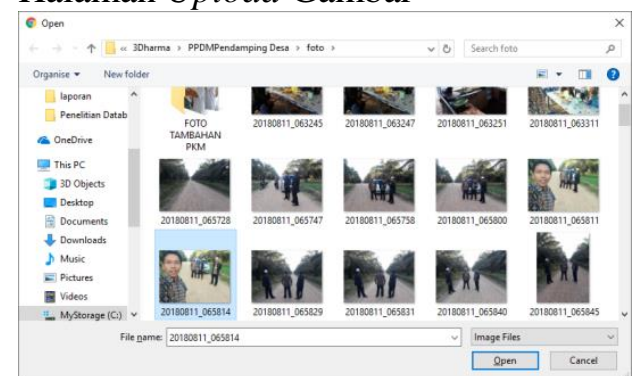

Gambar 10. Upload Gambar dari smartphone atau Desktop

7. Tampilan icon pada smartphone

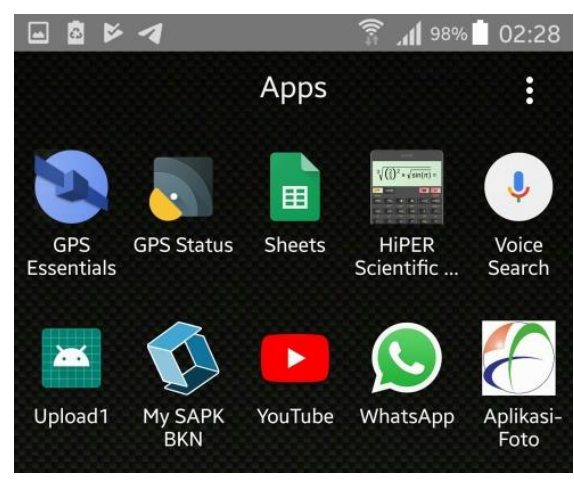

Gambar 11. Tampilan pada smartphone

8. Halaman Aplikasi Foto

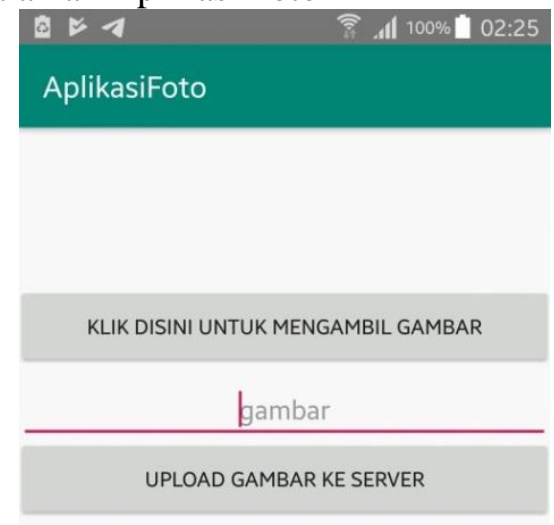

Gambar 12. Tampilan awal pada smartphone

\subsection{Pengujian Perangkat Lunak}

Pengujian menggunakan metoda black box.

Tabel 2. Hasil Pengujian login user

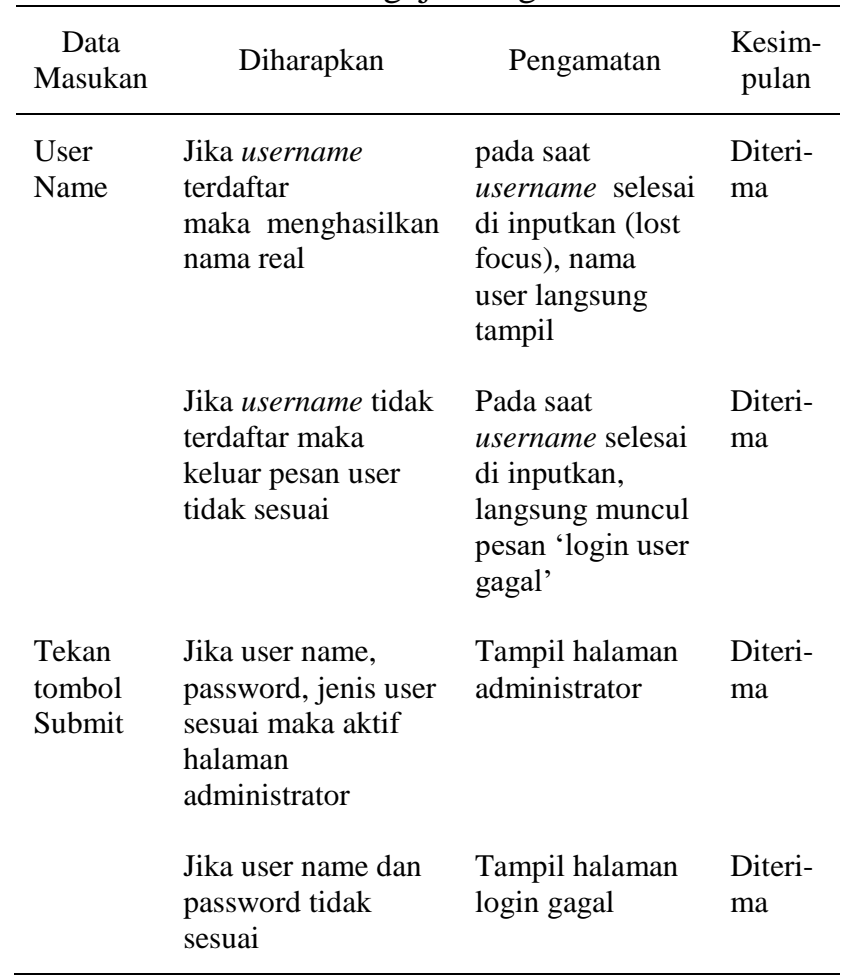


Tabel 3. Hasil PengujianPengambilan Gambar dari Smartphone

\begin{tabular}{|c|c|c|c|}
\hline $\begin{array}{l}\text { Data } \\
\text { masu- } \\
\text { kan }\end{array}$ & Diharapkan & Pengamatan & $\begin{array}{l}\text { Kesim } \\
\text { pulan }\end{array}$ \\
\hline \multirow[t]{2}{*}{ Gambar } & $\begin{array}{l}\text { Jika } \\
\text { mengambil } \\
\text { gambar } \\
\text { portrait sistem } \\
\text { menerima }\end{array}$ & $\begin{array}{l}\text { Pada saat } \\
\text { gambar diambil } \\
\text { secara portrait } \\
\text { sistem dapat } \\
\text { menerima } \\
\text { dengan baik }\end{array}$ & $\begin{array}{l}\text { Diteri- } \\
\text { ma }\end{array}$ \\
\hline & $\begin{array}{l}\text { Jika } \\
\text { mengambil } \\
\text { gambar } \\
\text { landscape } \\
\text { sistem } \\
\text { menerima }\end{array}$ & $\begin{array}{l}\text { Pada saat } \\
\text { gambar diambil } \\
\text { secara landscape } \\
\text { sistem dapat } \\
\text { tidak dapat } \\
\text { menerima }\end{array}$ & $\begin{array}{l}\text { Dito- } \\
\text { lak }\end{array}$ \\
\hline \multirow[t]{2}{*}{$\begin{array}{l}\text { Upload } \\
\text { gambar }\end{array}$} & $\begin{array}{l}\text { Jika } \\
\text { menggunakan } \\
\text { jaringan } \\
\text { operator } \\
\text { telekomunikas } \\
\text { i, sistem tidak } \\
\text { dapat diproses }\end{array}$ & $\begin{array}{l}\text { Pada saat } \\
\text { gambar diambil, } \\
\text { kemudian di } \\
\text { upload } \\
\text { menggunakan } \\
\text { jaringan } \\
\text { operator, proses } \\
\text { gagal }\end{array}$ & $\begin{array}{l}\text { Diter- } \\
\text { ima }\end{array}$ \\
\hline & $\begin{array}{l}\text { Jika } \\
\text { menggunakan } \\
\text { jaringan lokal, } \\
\text { sistem } \\
\text { memproses }\end{array}$ & $\begin{array}{l}\text { Pada saat } \\
\text { gambar diambil, } \\
\text { kemudian di } \\
\text { upload } \\
\text { menggunakan } \\
\text { jaringan lokal, } \\
\text { proses sukses }\end{array}$ & $\begin{array}{l}\text { Diteri- } \\
\text { ma }\end{array}$ \\
\hline
\end{tabular}

\section{SIMPULAN}

Kesimpulan yang dapat ditarik adalah:

1. Smartphone sistem operasi Android telah dapat di instal aplikasi pengambilan foto, tanpa ada yang dilakukan konfigurasi

2. pengambilan foto secara portrait.

3. Aplikasi menyediakan fasilitas sinkronisasi melalui jaringan internet.

4. Ukuran file berbanding lurus dengan waktu upload.

5. Sebanyak 3 bagian pengujian yang tidak sesuai dengan pengamatan

6. Sebanyak 10 bagian pengujian harapan dan hasil pengamatan sesuai.

7. Diperoleh tingkat kepercayaan, $76.5 \%$ dengan simpulan aplikasi dapat diterima.

\section{UCAPAN TERIMAKASIH}

TerimakasihkepadalembagaLembaga Penelitian dan Pengabdian STMIK Amik Riau, STMIK Amik Riau, dan Yayasan
Komputasi Riau yang telah mendanai penelitian ini.

\section{DAFTAR PUSTAKA}

Croci, G. A., Hoster, E., Beà, S., Clot, G., Enjuanes, A., Scott, D. W., Cabeçadas, J., Veloza, L., Campo, E., Clasen-Linde, E., Goswami, R. S., Helgeland, L., Pileri, S., Rymkiewicz, G., Reinke, S., Dreyling, M., \& Klapper, W. (2020). Reproducibility of histologic prognostic parameters for mantle cell lymphoma: cytology, Ki67, p53 and SOX11. Virchows Archiv. https://doi.org/10.1007/s00428-02002750-7

GlobalStats, S. (2019). alamatwebl. Statcounter GlobalStats. https://gs.statcounter.com/os-marketshare/ mobile/worldwide

Herdiansyah, H. (2019). Metodologi Penelitian Kualitatif untuk Ilmu-ilmu Sosial. In Penerbit Salemba (Vol. 5). yusuf.staff.ub.ac.id/files/2012/11/JurnalPenelitian-Kualitatif.pdf

Hidayat, T., Susanti, F., \& Siradj, Y. (2017). Implementasi Layanan Private Cloud Storage Menggunakan Owncloud Dan Monitoring Dengan Zenoss. EProceeding of Applied Science, 3(1), 112-125.

ID, K. (2019). Kualitas Kamera. Kamera.Id. https://kamera.id/perbedaan-kamera-slrdan-dslr/

Kurniawan, M. D., Hanafi, I. I., Bulan, T. F. D. K., \& Firmansyah, R. A. (2016). Design Dan Implementasi Cloud Storage Berbasis Web Pada Rt / Rw Net Maju Jaya. Seminar Nasional Teknologi Informasi Dan Multimedia 2016, 91-96.

Mahedy, K. S. (2017). Membangun Cloud Storage Berbasis Website. 236-246.

Oktafeearto, R., Ridarmin, R., \& Firman, C. E. (2019). Rancang Bangun Server Cloud Storage Mahasiswa Dan Dosen Menggunakan Owncloud Pada Jaringan Lokal Di Kampus Stmik Dumai. I N F O $\begin{array}{lllllllll}R & M & a & T & I & K & A, & 10(2), & 26 .\end{array}$ https://doi.org/10.36723/juri.v10i2.112

Santiko, I., \& Rosidi, R. (2018). Pemanfaatan Private Cloud Storage Sebagai Media Penyimpanan Data E-Learning Pada Lembaga Pendidikan. Jurnal Teknik Informatika, 10(2), 137-146. 
https://doi.org/10.15408/jti.v10i2.6992 Sudaryono. (2019). Metodologi Penelitian (1st ed.). PT RajaGrafindo Persada. https://ebooks.gramedia.com/id/buku/m etodologi-penelitian 